\section{Diabetic neuropathy and risk of diabetic foot syndrome during implementation of the national protocol in management of diabetes}

Tkachenko Victoria MD, PhD, Shupyk National Medical Academy of Postgraduate Education

\section{Summary}

The implementation of unified clinical protocol (UCP) has set a target to primary care physicians (PCP) to identify the diabetic neuropathy and angiopathy, screening the risk of diabetic foot syndrome and its prevention. The betic neuropathy, the risk of diabetic foot syndrome and level of type 2 diabetes control in patients of Kyiv region in terms of implementation of new clinical protocol in type 2 diabetes management. Materials and methods. The reports of health establishments of Kiev region were analyzed and 173 patients with type 2 diabetes were examined laged 55,13 $\pm 0,61$ years): group 1 - observed tients examination included laboratory tests of diabetes control and evaluation of the lower limbs by Neuropathy Disability Score and determination the «ankle-shoulder» index with the portable Doppler. Statistical analysis - Excel 2007, SPSS, Statistica 6.0. Results. Despite treatment, the average levels of blood glucose, HbA1c, lipidogramme exceeded target levels in patients with type 2 diabetes, indicating their lack of control. In this regard, at $7-9$ years of the disease in $19.65 \%$ of patients diabetic neuropathy of the lower limbs and in $15.03 \%$ of patients - occlusion, leading to the development of diabetic foot syndrome in $9.82 \%$ of patients, and $70.52 \%$ of the patients had moderate $(44.51 \%)$ or high $(26.01 \%)$ risk of its development. The differences between patients of PCP and endocrinologists were not found. However, the significant decrease of neuropathy and angiopath Kiev region and reducing the number of amputations for 2012-2014 demonstrates the positive effect of the implementation of UCP. Conclusion. The frequency of diabetic neuropathy and angiopathy of lower limbs, the number of amputations in Kiev region decreased, that indicates positive effect of implementation of UCP, but the risk of diabetic foot syndrome in patients remains high due to physicians and specialists that require optimization.
Key words: diabetic neuropathy, diabetic foot syndrome, primary care, implementation of new clinica protocol

According to the data of International Diabetes ederation (IDF) the number of diabetic patients in the world in 2015 reached 415 million people ( $8.8 \%$ of the population). It is predicted that by 2030 this figure will rise to 552 million (9.9\% or 1 diabetic patients on 10 healthy adults), and by 2040 - up to 642 million $(10.4 \%)$. About $90 \%$ of all cases of diabetes in the world connected with type 2 diabetes [1].The most dangerou consequences of the global epidemic of diabetes are its lar disease of the lower limbs, diabetic foot syndrome, nephropathy, retinopathy, destruction of major vessels of the heart, the brain, which are the major cause of disabiity, especially among the working population, causing increase of mortality in 2-3 times and reduce of life expectancy by $10-30 \%[1-3]$

The prevalence of neuropathy in patients with type 2 diabetes of the world is $13,1-45,0 \%$, nephropathy about $-18,9-42,1 \%$ retinopathy $-10,1-55,0 \%$, amputations $0,2-4,8 \%$ [2]. Mortality from diabetes is $8.4 \%$ of global mortality among working-age population, the highest mortality recorded in China, India, the USA, the Russian Federation [3].

After approval in Ukraine the order of Health Ministry of Ukraine from 21.12.2012 №1118 «About approv and implementation of medico-technological documellitus tyandardization of medical care in diabetes mellitus type $2 »$ and implementation of unified clinical protocol (UCP) in diabetes management, the primary carry out the identification of diabetic neurosathy and carry out the identification of diabetic neuropathy and ing to identify the risk of dia loweric foot syndrome and is prevention [4-8]. prevention [4-8]. complications - neuropathy, lesions of peripheral vascubasic laboratory indexes of diabetes control: the level of For the purpose of screening and identifying the risk
The aim of our research - to determine the frequency of diabetic neuropathy, the risk of diabetic foot syndrome and level of type 2 diabetes control in patients of Kyiv region during implementation of new clinical protocol in type 2 diabetes management.

and a. tibialis posterior) by palpation of pulsation and portable Doppler determination of "ankle-shoulder" insoftware, SPSS, Statistica 6.0 .

Materials and methods. After improvement of the order of Health Ministry of Ukraine from 21.12.2012 number 1118 [4-6] we analyzed the reports of health establishments in Kiev region and examined 173 patients with type 2 diabetes (aged 55,13 $\pm 0,61$ years, 112 women and $61 \mathrm{men}$ ), which were divided into 2 groups, depending on the doctor they observed: 1st - by PC physicians ( $\mathrm{n}=45$, age $54,95 \pm 1,2$ years, 23 of them - were treated by tablets, 22 treated with insulin), 2 nd group - by the endocrinologist $(n=128$, age $55,23 \pm 0,71$ years, 48 of them - were treated by tablets, 80 received insulin). The clinical efficacy in patients were studied by glycated hemoglobin - HbAlc, fasting blood glucose, indexes of lipidogramme. The 40 patients with the same age without diabetes were examined for comparison. of diabetic foot syndrome we conducted evaluation of the lower limbs by identifying diabetic neuropathy with appropriate neurological sets (monofilaments, tuning fork, neurological hammers), scale of neurological dysfunctional calculation (Neuropathy Disability Score), and evaluate the state of the foot vessels (a. dorsalis pedis

Results and Discussion. The prevalence of type 2 diabetes in the Kiev region in 2012-2014 continued to grow, confirming the global trends - the growth amounted to $7,56 \%$ from 343.30 per 10 thousand population to 319.18 per 10 thousand population $(p<0,01)$. The incidence of type 2 diabetes in the Kiev region in 20102012 years significantly increased on $17.10 \%$ (from 21.52 to 25.2 per 10 thousand pop., $\mathrm{p}<0,01$ ), and in 2012-2014 years - were stabilized [5-8].

Proportion of diabetic neuropathy and angiopathy of lower limbs in the Kiev region over the past 5 years was on average $23-26 \%$, which corresponds to the average prevalence in the world. For the 2012-2014 proportion of neuropathy and angiopathy of lower limbs was significantly decreased in patients with type 2 diabetes in Kyiv region (Table 1) with the authentic growth of the incidence of eye damage.

\section{Table 1.}

The incidence of type 2 diabetes complications among patients of Kiev region

\begin{tabular}{|c|c|c|c|c|c|c|c|c|c|c|}
\hline \multirow{2}{*}{$\begin{array}{l}\text { Diabetic Compli- } \\
\text { cations }\end{array}$} & \multicolumn{2}{|c|}{2010} & \multicolumn{2}{|c|}{2012} & \multicolumn{2}{|c|}{2014} & \multicolumn{2}{|c|}{$\begin{array}{c}\text { Increase } \\
2010-2012, \%\end{array}$} & \multicolumn{2}{|c|}{$\begin{array}{c}\text { Increase } \\
\text { 2012-2014,\% }\end{array}$} \\
\hline & $\mathrm{N}$ & $\%$ & $\mathrm{~N}$ & $\%$ & $\mathrm{~N}$ & $\%$ & $\mathrm{~N}$ & $\%$ & $\mathrm{~N}$ & $\%$ \\
\hline Nephropathy & 1848 & 8,05 & 2261 & $8,80^{*}$ & 2405 & 8,68 & 22,35 & 9,32 & 6,37 & $-1,36$ \\
\hline Retinopathy & 2472 & 10,77 & 6198 & $24,13^{* *}$ & 7614 & $27,49 \# \#$ & 150,73 & 124,05 & 22,85 & 13,92 \\
\hline Diabetic cataract & 5978 & 26,06 & 3090 & $12,03^{* *}$ & 3552 & $12,82 \#$ & $-48,31$ & $-53,84$ & 14,95 & 6,57 \\
\hline neuropathy & 6162 & 26,86 & 6415 & $24,97^{7 *}$ & 6415 & $23,16 \# \#$ & 4,11 & $-7,04$ & 0,00 & $-7,25$ \\
\hline Diabetic foot & 583 & 2,54 & 662 & 2,58 & 662 & 2,39 & 13,55 & 1,57 & 0,00 & $-7,36$ \\
\hline $\begin{array}{l}\text { Angiopathy of } \\
\text { limbs }\end{array}$ & 5756 & 25,09 & 6878 & $26,77^{* *}$ & 6878 & $24,83: \#$ & 19,49 & 6,70 & 0,00 & $-7,25$ \\
\hline Diabetic gangrene & 144 & 0,63 & 185 & 0,72 & 176 & 0,64 & 28,47 & 14,29 & $-4,86$ & $-11,11$ \\
\hline Total & 22943 & 100 & 25689 & 100 & 27702 & 100 & 11,97 & 0,00 & 7,84 & 0,00 \\
\hline
\end{tabular}

Note: ${ }^{* *}-p<0,01,{ }^{*}-p<0,05$ - the difference between the indexes statistically significant compared with 2010 , \#\# - $p$ $<0,01, \#-\mathrm{p}<0,05$ - compared with 2012 by Student's test 
Number of amputations related to diabetes, and their prevalence in the population decreased significantly at $6.31 \%$ in the Kiev region over the past 2 years (2012$2014)$ and significantly in Ukraine to $16.09 \%(\mathrm{p}<0,01)$, indicating the improvement of diabetes care and preventive measures in lower limbs care in Kiev region and Ukraine, but Kiev region index was significantly higher than the figure for Ukraine, indicating worse situation in this region (Table. 2).

\section{Table 2.}

Number of lower limb amputations related to

diabetes, for 2010-2014

Results of examination of patients with type 2 diabetes (Table 3 ) showed that the average blood glucose level $(8,65 \pm 0,22 \mathrm{mmol} / \mathrm{l}, \mathrm{p}<0,01)$ and HbAlc $(9,00 \pm$

general population $(5.2 \mathrm{mmol} / \mathrm{l}$ by NCEP classification) Violation of lipid metabolism was confirmed by exceedcantly increased in patients with diabetes in contrast to the comparison group: TG levels $(1,74 \pm 0,15$ to $1,11 \pm$ $0,08 \mathrm{mmol} / \mathrm{l}, \mathrm{p}<0,01$ recommended $<1.7 \mathrm{mmol} / \mathrm{l}), \mathrm{LDL}$ cholesterol $(2,71 \pm 0,18$ to $1,34 \pm 0,04 \mathrm{mmol} / \mathrm{l}, \mathrm{p}<0,01$, recommended $<2.5 \mathrm{mmol} / \mathrm{l})$ and $\operatorname{VLDL}(0,63 \pm 0,06$ to $0,42 \pm 0,03 \mathrm{mmol} / 1, \mathrm{p}<0,01)$ and significant decrease in $\operatorname{HDL}(2,19 \pm 0,14$ to $3,51 \pm 0,18 \mathrm{mmol} / \mathrm{l}, \mathrm{p}<0,01$ within recommended $>1 \mathrm{mg} / 1)$, indicating the presence of dyslipidemia. Atherogenic index was higher then recommended in both groups. Significant difference in glicemic and lipid control between endocrinologists and PC physicians were not found. The level of CRP as one indicator of atherogenic process in patients with diabetes

\begin{tabular}{|c|c|c|c|c|}
\hline \multirow{2}{*}{ Year } & \multicolumn{2}{|c|}{ Kiev region } & \multicolumn{2}{c|}{ Ukraine } \\
\cline { 2 - 5 } & $N$ & per 10 thous. pop. & $N$ & $\begin{array}{c}\text { per 10 thous. } \\
\text { pop. }\end{array}$ \\
\hline 2010 & 144 & 1,02 & 3578 & 0,91 \\
\hline 2011 & 166 & $1,18 \# \#$ & 3382 & 0,86 \\
\hline 2012 & 156 & $1,11 \#$ & 3370 & 0,87 \\
\hline 2013 & 133 & 0,94 & 3098 & 0,83 \\
\hline 2014 & 147 & $1,04 \# \#$ & 2656 & $0,73 * *$ \\
\hline Increase 2010-2012, \% & 8,33 & 8,82 & $-5,81$ & $-4,40$ \\
\hline Increase 2012-2014, \% & $-5,77$ & $-6,31$ & $-21,19$ & $-16,09$ \\
\hline
\end{tabular}

Note:
$* *-p<0,01$ - the difference between the indexes statistically significant compared to 2012 by Student's test,

$\#$ \# - $<<0,01$ \# - $\mathrm{p}<0,05$ - compared to Ukraine of the corresponding year

$0,18 \%, \mathrm{p}<0.01)$ were higher than recommended target levels by UCP, indicating a lack of compensation of disease despite treatment. This significant difference between patients of PC physicians and endocrinologists are not observed. The recommended level of HbA1c (individualized $<6.5-7.5 \%$ ) had $31.58 \%$ of patients observed PC physicians and $24.24 \%$ of patients of endocrinologists. Blood Prssure (BP) did not exceed the recommended rates in bohh groups, although patients in comparison group had slightly elevated levels of systolic BP in the fiss measurement. The level of total was higher tan rocom diabetes $(4.5 \mathrm{mmol} / \mathrm{l})$ and upper then

was 5,42 $\pm 0,92 \mathrm{mg} / \mathrm{l}$ and exceeded the normal level of $0-5 \mathrm{mg} / \mathrm{l}$, and was not significantly different from the evel in comparison group. But according to the American Heart Association and the US Centers for Disease Control and Prevention even the level of CRP higher of $3 \mathrm{mg} / \mathrm{l}$, which was observed in both groups, suggests a high risk of cardiovascular pathology [8-11]. Another cardiovascular risk factor is the level of uric acid, it did not exceed the recommended norms in patients with diabetes (for women $-150-360 \mathrm{mmol} / /$, for men - 210-420 (n) contrast to the level of men with type 2 dib $p<0$ ( 310,60 $\pm 19,44 \mathrm{mmol} / 1$ ) $\pm 19,44 \mathrm{mmol} / \mathrm{l}$ ).
Table 3.

The clinical and laboratory evaluation of diabetes control in patients of PC physicians and endocrinologists

The examination of the lower limbs (tab. 4) showed that $11.56 \%$ of patients with type 2 diabetes had ulceration or amputation of the foot in history During the inspection the change of skin color or skin atrophia of limbs was found in $24.86 \%$ of patients, $7.51 \%$ of patients
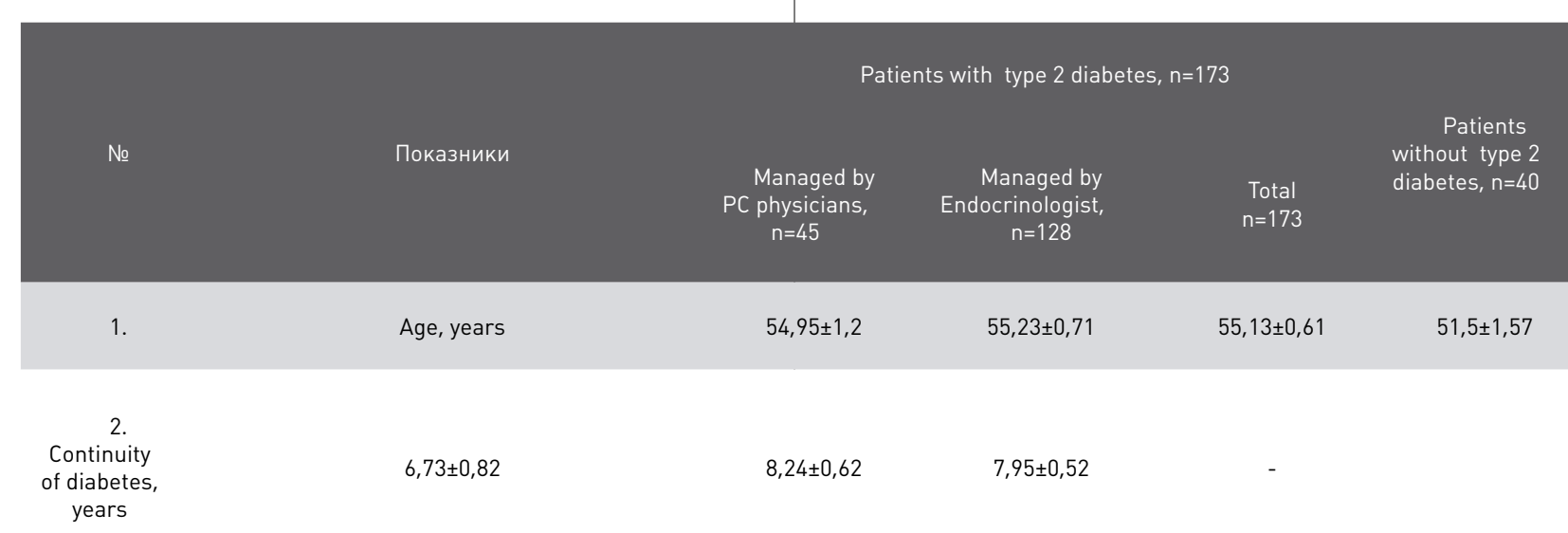

$54,95 \pm 1,2$

$8,24 \pm 0,62$

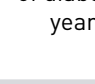

\begin{tabular}{|c|c|c|c|c|c|}
\hline 3. & Systolic BP, $\mathrm{mm} \mathrm{Hg}, 1^{1 \mathrm{ts}}$ measurement & $140,04 \pm 2,85$ & $140,24 \pm 1,80$ & $140,19 \pm 1,52$ & $144,44 \pm 4,72$ \\
\hline 4. & Diastolic BP, $\mathrm{mm} \mathrm{Hg}, 1^{15 \mathrm{t}}$ measurement & $85,84 \pm 1,33$ & $85,94 \pm 1,16$ & $85,91 \pm 0,92$ & $88,41 \pm 3,06$ \\
\hline 5. & Systolic BP, $\mathrm{mm} \mathrm{Hg}$, 2nd measurement & $133,77 \pm 2,65$ & $134,23 \pm 1,51$ & $134,11 \pm 1,31$ & $140,62 \pm 4,52$ \\
\hline 6. & Diastolic BP, mm Hg, 2nd measurement & $82,36 \pm 1,32$ & $82,43 \pm 0,98$ & $82,41 \pm 0,80$ & $85,0 \pm 2,73$ \\
\hline 7. & Blood glucose, mmol/l & $8,46 \pm 0,49^{*}$ & $8,73 \pm 0,25{ }^{*}$ & $8,65 \pm 0,22^{*}$ & $4,76 \pm 0,09$ \\
\hline 8. & $\mathrm{Hb} 1 \mathrm{Ac}, \%$ & $8,74 \pm 0,37 *$ & $9,10 \pm 0,21{ }^{*}$ & $9,00 \pm 0,18^{\prime \prime}$ & $5,31 \pm 0,09$ \\
\hline 9. & Total cholesterol, $\mathrm{mmol} / \mathrm{I}$ & $5,27 \pm 0,21$ & $5,73 \pm 0,16$ & $5,60 \pm 0,13$ & $5,35 \pm 0,20$ \\
\hline 10. & $T G, \mathrm{mmol} / \mathrm{l}$ & $1,70 \pm 0,32$ & $1,76 \pm 0,17^{* \prime}$ & $1,74 \pm 0,15^{\prime \prime}$ & $1,11 \pm 0,08$ \\
\hline 11. & $\mathrm{HDL}, \mathrm{mmol} / \mathrm{I}$ & $2,30 \pm 0,23^{*}$ & $2,14 \pm 0,17^{\prime \prime}$ & $2,19 \pm 0,14^{\prime \prime}$ & $3,51 \pm 0,18$ \\
\hline 12. & LDL, $\mathrm{mmol} / \mathrm{I}$ & $2,29 \pm 0,28^{* \prime}$ & $2,91 \pm 0,23^{*}$ & $2,71 \pm 0,18^{\prime \prime}$ & $1,34 \pm 0,04$ \\
\hline 13. & VLDL, mmol/I & $0,59 \pm 0,07$ & $0,65 \pm 0,08^{\circ}$ & $0,63 \pm 0,06^{\prime \prime}$ & $0,42 \pm 0,03$ \\
\hline 14. & Atherogenic index & $3,30 \pm 0,21$ & $3,30 \pm 0,14$ & $3,30 \pm 0,12$ & $3,10 \pm 0,14$ \\
\hline 15. & $\mathrm{CRP}, \mathrm{mg} / \mathrm{I}$ & $5,63 \pm 2,02$ & $5,34 \pm 1,03$ & $5,42 \pm 0,92$ & $3,79 \pm 0,16$ \\
\hline 16. & Uric acid in women, $\mathrm{mmol} / \mathrm{l}$ & $311,11 \pm 23,22$ & $301,99 \pm 19,66$ & $304,08 \pm 15,98$ & $272,36 \pm 16,27$ \\
\hline 17. & Uric acid in men, $\mathrm{mmol} / \mathrm{l}$ & $295,41 \pm 36,75^{\circ}$ & $315,67 \pm 23,24^{\circ}$ & $310,60 \pm 19,44^{\prime \prime}$ & $412,11 \pm 25,88$ \\
\hline
\end{tabular}

Notes:
${ }^{*}-\mathrm{p}<0,01,{ }^{*}-\mathrm{p}<0,05-$ the difference between the indexes is statistically significant by Student's test compared to the control group 
had a foot deformity, 3,47\% trophic ulcers. Symptoms of moderate diabetic neuropathy of the lower limbs by NDS index had $36.42 \%$ of patients, severe neuropathy $19.65 \%$ of patients. The significant differences between patients of PC physicians and endocrinologists haven't been identified, the average NDS index was 10,92 $\pm 1,11$ and $11,57 \pm 0,65$ points. Palpation of lower limbs defined reduced pulsation in $59.53 \%$ of patients, and occlusion was confirmed by Doppler measurement in $15.03 \%$ of patients. In general, that $9.82 \%$ patients had determined diabetic foot syndrome, $26.01 \%$ of patients had high risk of diabetic foot syndrome, $44.51 \%$ - moderate risk Significant differences between patients PC physicians and endocrinologists undefined.

\section{Table 4.}

Diabetic foot syndrome risk in patients of PC physicians and endocrinologists.

\begin{tabular}{|c|c|c|c|}
\hline $14,06 \% 11,56 \%$ Indexes & $\begin{array}{l}\text { Man- } \\
\text { aged by } P C \\
\text { physicians, } \\
n=45\end{array}$ & $\begin{array}{c}\text { Managed by } \\
\text { Endocrinologist, } \\
n=128\end{array}$ & $\begin{array}{c}\text { Total } \\
n=173\end{array}$ \\
\hline $\begin{array}{l}\% \text { of patients with changes in color or trophic } \\
\text { skin changes of the lower limbs } 4,44 \% \\
\% \text { of patients with limb ulcers or amputation in } \\
\text { history }\end{array}$ & $20,0 \%$ & $26,56 \%$ & $24,86 \%$ \\
\hline$\%$ patients with foot deformities & $8,89 \%$ & $7,03 \%$ & $7,51 \%$ \\
\hline $\begin{array}{l}\% \text { patients with existing trophic ulcer } \\
\qquad 11,42 \pm 0,56 \\
11,57 \pm 0,65\end{array}$ & $0 \%$ & $4,69 \%$ & $3,47 \%$ \\
\hline $\begin{array}{c}\% \text { patients with index NDS } 14-28 \text { points - severe } \\
\text { neuropathy } \\
10,92 \pm 1,11 \\
\text { Identification of neuropathy } \\
\text { Average index NDS, score }\end{array}$ & $15,56 \%$ & $21,09 \%$ & $19,65 \%$ \\
\hline $\begin{array}{l}\% \text { patients with index NDS } 5-13 \text { points - } \\
\text { moderate neuropathy }\end{array}$ & $35,56 \%$ & $36,72 \%$ & $36,42 \%$ \\
\hline$\%$ patients with low pulse palpation of foot vessels & $46,67 \%$ & $64,06 \%$ & $59,53 \%$ \\
\hline $\begin{array}{l}\text { Doppler measurement of } \\
\text { Index "ankle-arm" on the right }\end{array}$ & $0,99 \pm 0,07$ & $0,91 \pm 0,07$ & $1,01 \pm 0,03$ \\
\hline Index "ankle-arm" on the left & $1,01 \pm 0,03$ & $1,06 \pm 0,02$ & $1,03 \pm 0,02$ \\
\hline$\%$ patients with Index «ankle-arm" $<0,9$ & $15,56 \%$ & $14,84 \%$ & $15,03 \%$ \\
\hline $\begin{array}{l}\% \text { patients with high total risk of diabetic foot } \\
\text { syndrome }\end{array}$ & $20,0 \%$ & $28,13 \%$ & $26,01 \%$ \\
\hline $\begin{array}{c}\% \text { patients with moderate total risk diabetic foot } \\
\text { syndrome }\end{array}$ & $35,56 \%$ & $47,66 \%$ & $44,51 \%$ \\
\hline$\%$ patients with present diabetic foot syndrome & $8,89 \%$ & $10,15 \%$ & $9,82 \%$ \\
\hline
\end{tabular}

Thus, despite treatment, the average levels of blood glucose, $\mathrm{HbAlc}$, lipidogramme indexes exceeded target performance levels recommended UCP in patients with regard, at $7-9$ years of the disease the signs of severe diregard, at $7-9$ years of the disease the signs of severe di-
abetic lower limbs neuropathy were founded in $19.65 \%$ of patients, moderate neuropathy in $36.42 \%$ of patients and occlusion of lower limbs in $15.03 \%$ patients, leading to the development of diabetic foot syndrome in $9.82 \%$ patients, and $70.52 \%$ of the patients had the moderate $(44.51 \%)$ or high (26.01\%) risk of its development. The results indicated insufficient annual monitoring of patients with diabetes, insufficient of primary and secondary preventive measures, the same as by PC physicians and by endocrinologists. But the significant decrease of neuropathy and angiopathy of lower limbs in patients with type 2 diabetes in the Kiev region for the 2012-2014 years, reduce in the number of amputations demonstrate

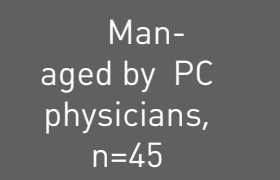

the positive effect of the implementation of UCP. 4. Про затвердження та впровадження медико-
технологічних документів зі стандартизації медичної допомоги при цукровому діабеті 2 типу : наказ МОЗ України від 21.12.2012 № 1118. ua/portal/dn_20121221_1118.html

5. Ткаченко В.І. Співвідношення альбумінкреатинін сечі та швидкість клубочкової фільтрації як фактори ризику серцево-судинної патологі у хворих з цукровим діабетом 2 типу /B.I. Ткаченк //The Unity of Science. - 2015. - November. - C. 105-109.

6. Лисенко Г.І. Диспансеризація як шлях первинноі і вторинної профілактики цукрового діабету 2-го типу на етапі первинноі медичноі допомог (навчально-методичний посібник) / Г.І. Лисенко, B.I. Ткаченко. - К., 2013. - 144 с

7. Ткаченко В.I. Розробка та впровадження уніфікованого та локального протоколів з надання медичної допомоги при цукровому діабеті 2 типу на етапі первинної медичної допомоги / В.I. Ткаченко // Методичн рекомендації. - Київ, 2014. - 94 с.

8. Порівняльний аналіз основних показників здоров’я населення та кадрового забезпечення діабетологічної допомоги в Київській області в умовах впровадження медико-технологічних документів (2010-12 pp. i 2012-2014 pp.) / В.І. Ткаченко, Б.М. Маньковський, Н.В.
Видиборець, О.Ф Коваленко // Міжнароднии Видиборець, О.Ф Коваленко // Міжнародний
ендокринологічний журнал. - 2015. - №5 (69). Сндокринол

9. Kailash Prasad. Reducing the Risk: Measures to Lower CRP in CVD / Kailash Prasad // Perspectives in Cardiology. 2007, Febrary. - P. $31-34$

0. Mora S, et al. The clinical utility of High-sensitivity C-reactive proten in Cardiovascular disease and the tice // Guidelines clinical chemistry. - 2009. - Vol.
55. - P.2219-2228.

11. Rutter MK. C-reactive protein, the metabolic syndrome, and prediction of cardiovascular events in the Framingham Offspring Study / MK Rutter, JB Meigs, et al. // Circulation. - 2004. - Vol. 110. P. $380-385$.

Діабетична нейропатія і ризик розвитку синдрому діабетичної стопи в умовах впровадження національного протоколу з управління діабетом

\section{Ткаченко В.І.} Національна медична академія
післядипломної освіти імені П.Л. Шупика

\section{Резюме.}

Впровадження унінікованого клінічного протоколу (УКП) з ведення цукрового діабету 2 типу (ЦД 2) поставило завдання перед лікарем первинної медичноі допомоги (ПМД) проводити ідентифікацію діабетичної нейропатії та ангіопатії, скринінг на виявлення ризику розвитку діабетичної стопи та ї профілактику. Мета нашого дослідження - визначити частоту діабетичної нейропатії, ризик розвитку синдрому діабетичної стопи та рівень контролю ЦД 2 у пацієнтів Київської області в умовах впровадження нового УКП з надання допомоги при ЦДД 2. Матеріали та методи. Проаналізовані звіти закладів охорони здоров я Киівської област

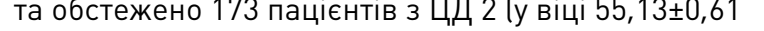
років): 1 -а група - спостерігалися у лікаря ПМД $(n=45)$, 2-я група - у лікаря ендокринолога (n=128). Пацієнтам проводили дослідження основних лабораторних показників контролю діабету та оцінку стану нижніх кінцівок за шкалою неврологічного дисфункціонального розрахунку (Neuropathy Disability Score) та визначення індексу щиколотка-плече за допомогою портативного доплера. Статистичний аналіз - Excel 2007, SPSS, Statistica 6.0. Результати. Не дивлячись на лікування, у пацієнтів з ЦД 2 середні рівні глюкози крові, НbА1с, показників ліпідограми перевищували цільові рівні показників, що свідчить про іх недостатній контроль. У зв язку з цим на 7-9 роках захворювання у $19,65 \%$ пацієнтів виявлено ознаки вираженої і у $36,42 \%$ помірної діабетичної нейропатії нижніх кінцівок та у 15,03\% пацієнтів - оклюзію судин нижніх кінцівок, що призвело до розвитку синдрому діабетичної ступні у 9,82 \% пацієнтів і ще 70,52\% пацієнтів знаходились у групі помірного $(44,51 \%)$ чи високого $(26,01 \%)$ ризику iा розвитку. Різниці між пацієнтами лікарів ПМД і ендокринологів не виявлено. Але, достовірне зниження за 2012-2014 pp. питомоі вағи нейропатіі та ангіопатії нижніх кінцівок у хворих на ЦДД 2 в Киівській області, зниження кількості ампутацій свідчить про позитивний ефект впровадження УКП. Висновок. Частота діабетично нейропаніі та ангіопаніг нижніх кінцівок, кількість ампутацій в Киівській області знизились, що але ризик розвитку синдрому діабетичної стопиу

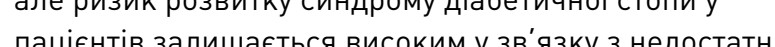
поцієнтів залишаеться високим узв'язку з недостатн 
винної і вторинної ланок, що потребує оптимізації. Ключові слова: діабетична нейропатія, синдром діабетичної стопи, первинна медична допомога, впровадження нового клінічного протоколу

\section{Диабетическая нейропатия и риск развития} синдрома диабетической стопы в условиях внедрения национального протокола по управлению диабетом

\section{Ткаченко В.И.} дипломного образования имени П.Л. Шупика

\section{Резюме}

Внедрение унифицированного клинического протокола (УКП) по ведению сахарного диабета 2 типа (СД 2) поставило задачу перед врачом первичной медицинской помощи (ПМП) проводить идентификацию диабетической нейропатии и ангиопатии, скрининг на выявление риска развития диабетической стопы и их профилактику. Цель нашего исследования определить частоту диабетической нейропатии, риск развития синдрома диабетической стопы и уровень контроля СД 2 типа у пациентов Киевской области в условиях внедрения нового УКП по оказанию помощи при СД2. Материалы и методы. Проанализированы отчеты учреждений здравоохранения Киевской области и обследовано 173 пациентов с СД 2 (в возрасте $55,13 \pm 0,61$ лет): 1 группа - наблюдались у врача

ПМП $(n=45), 2$-я группа - $у$ врача эндокринолога $(n=$ 128). Пациентам проводили исследования основных лабораторных показателей контроля диабета и оценку состояния нижних конечностей по шкале неврологического дисфункционального счета (Neuropathy Disability Score) и определение "лодыжечно-плечевого индекса с помощью портативного допплера. Статистический анализ - Excel 2007, SPSS, Statistica 6.0. Результаты. Несмотря на лечение, у пациентов с СД 2 средние уровни глюкозы крови, НbA1с, показателей липидограммы превышали целевые уровни, что свидетельствует об их недостаточном контроле. В связи с этим на 7-9 годах заболевания в 19,65\% пациентов выявлены признаки выраженной и в 36,42\% - умеренной диабетической нейропатии нижних конечностей и у $15,03 \%$ пациентов - окклюзии сосудов нижних конечностей, что привело к развитию синдрома диабетической стопы у 9,82\% пациентов и еще $70,52 \%$ пациентов находились в группе умеренного $(44,51 \%)$ или высокого $(26,01 \%)$ риска ее развития. Разницы между пациентами врачей ПМП и эндокринологов не обнаружено. Но, достоверное снижение по 2012-2014 пт. удельного веса нейро патии и ангиопатии нижних конечностей у больных СД 2 типа в Киевской области, снижение количества ампутаций свидетельствует о положительном эффекте внедрения УКП. Вывод. Частота диабетической нейропатии и ангио пании нижних конеиностей, колитесво ампутаций в Киевской области снизились, что свидетельствует развития синдрома диабетической стопы у пациентов
остается высоким в связи с недостаточным контролем СД 2 типа со стороны пациентов и врачей первичного и вторичной звеньев, что требует оптимизации.

Ключевые слова: диабетическая нейропатия, синдром диабетической стопы, первичная медицинская помощь, внедрение нового клинического протокола

\section{TIBOPTIH $^{\circ}$}

achapmam
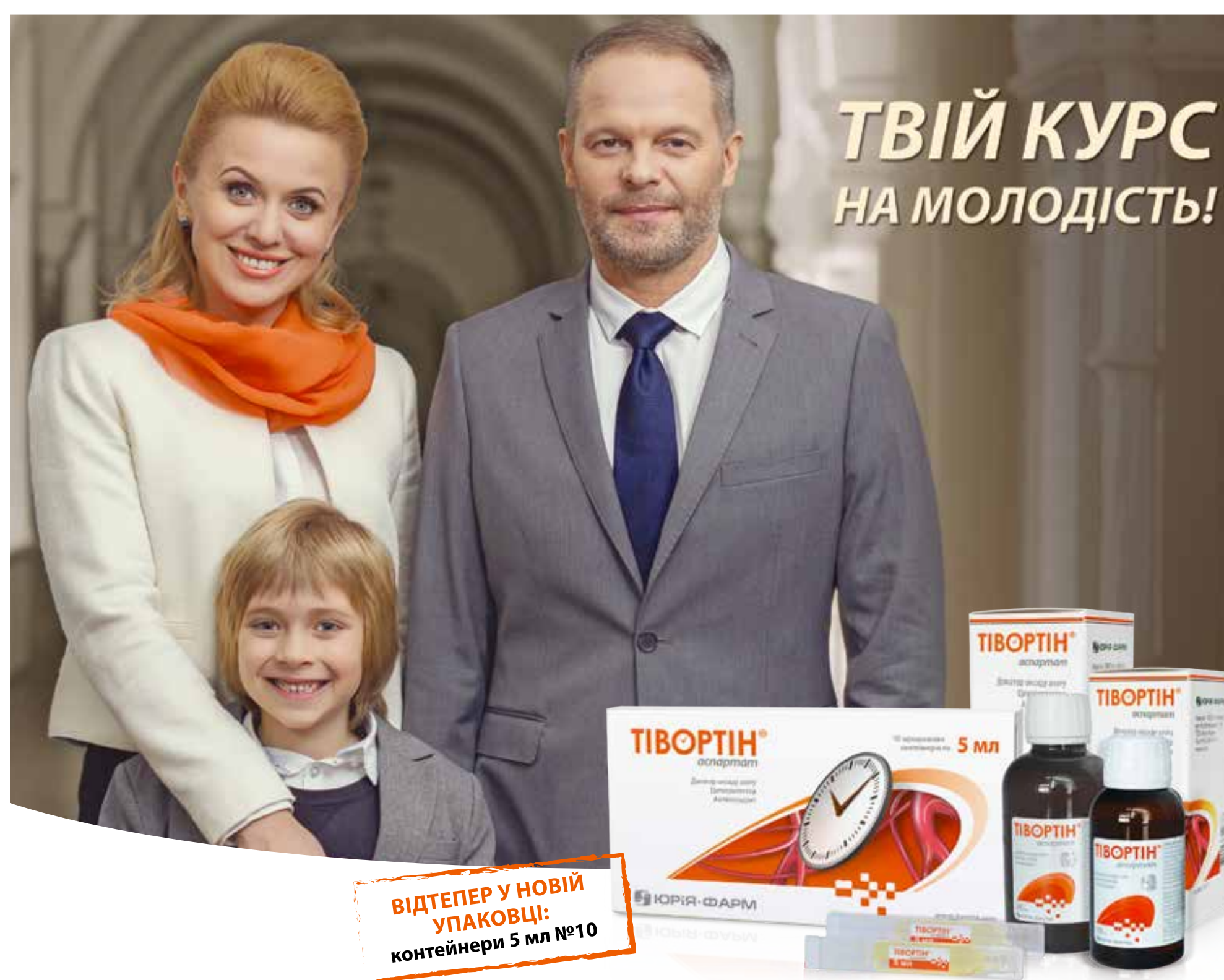

\section{MІСЦЦЕ ДIÏ ТІВОРТІНУ АСПАРТАТУ - СТІНКА СУДИНИ}

- Тівортін ${ }^{\circledR}$ аспартат розширює спазмовані судини та сприяє відновленню кровообігу, порушеного атеросклерозом.

- Тівортін ${ }^{\circledR}$ аспартат перешкоджає прилипанню клітин крові та холестерину до стінки судини, що сприяє профілактиці утворення і розвитку атеросклерозу

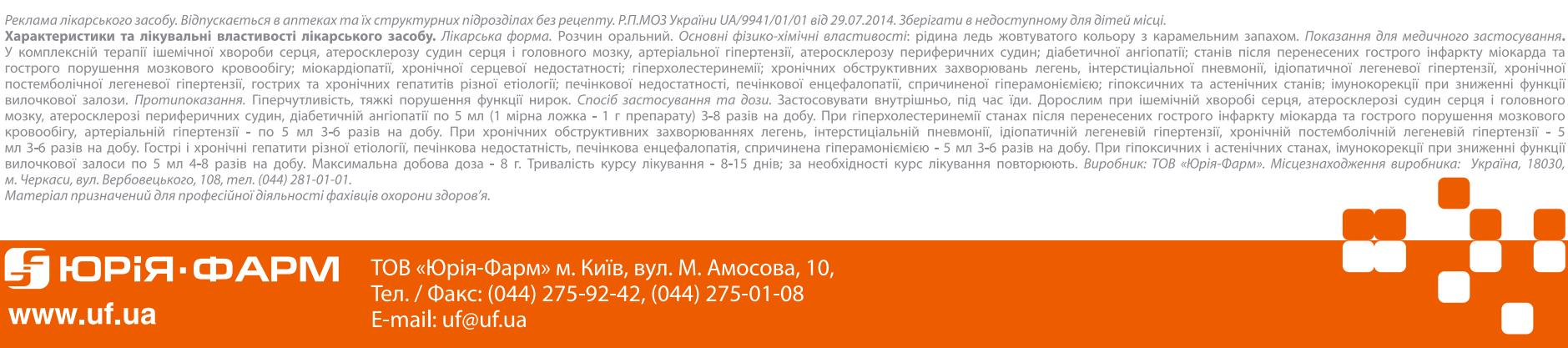

